\title{
Study on intraoral distribution of dental plaque
}

\author{
Studiu privind distribuţia plăcii microbiene la nivelul suprafeţelor dentare
}

Cristian Funieru1, Ruxandra Ionela Sfeatcu²
Unisciplina de Prevenţie Oro-Dentară, Facultatea de Medicină Dentară,
Universitatea de Medicină şi Farmacie „Carol Davila“, Bucureşti, România
2Disciplina de Sănătate Orală şi Stomatologie Comunitară, Facultatea de Medicină Dentară, Universitatea
de Medicină şi Farmacie „Carol Davila“, Bucureşti, România

\begin{abstract}
Introducere. Realizarea tiparului de acumulare al plăcii dentare este important atât pentru stabilirea modelu-lui patologiei oro-dentare, cât şi pentru stabilirea design-ului programelor preventive individualizate. Materiale şi metodă. Prezenta cercetare reprezintă un studiu pilot realizat pe un lot de 15 pacienţi cu vârste cuprinse între 20 şi 38 de ani, la care s-au luat în considerare 223 de dinţi (892 de suprafeţe dentare laterale). Pentru realizarea distribuţiei plăcii microbiene s-a folosit indicele de placă O'Leary.

Rezultate. Placa dentară a fost găsită mai frecvent pe suprafeţele dentare maxilare, iar pe cele aproximale s-a observat în mod constant mai multă placă microbiană decât pe cele vestibulare sau orale.

Concluzii. Programele preventive individualizate ar trebui să ţină cont atât de acest tipar generalizat (acumulare de placă pe feţele aproximale), cât şi de factorii care ţin de individ: înghesuiri dentare, consum de crescut de hidrocarbonate etc.

Cuvinte cheie: placă bacteriană, distribuţie, suprafeţe dentare

ABSTRACT

Introduction. Discovering the dental plaque accumulation model is important for establishing the oro-dental pathological pattern as well as for establishing individualized prevention programs.

Materials and method. Our work is a pilot study developed on a group of 15 patients aged 20-38 years, which involved 223 teeth (892 dental surfaces). The O'Leary plaque index was used in order to assess the dental plaque distribution (accumulation pattern).

Results. The dental plaque was found mostly on the maxillary dental surfaces, especially on proximal surfaces (consistently than the vestibular or oral ones).

Conclusions. Individualized oral preventive programs should be based on this general pattern (dental plaque accumulation on proximal surfaces) as well as individual risk factors: dental crowding, increased sweets consumption etc.
\end{abstract}

Keywords: dental plaque, distribution, dental surfaces

\section{INTRODUCERE}

Controlul plăcii dentare reprezintă un aspect important în promovarea sănătăţii la nivel individual şi comunitar, având în vedere că aceasta este factor de risc comun în apariţia cariei şi inflamaţiei parodontale. Periajul dentar personal este una dintre principalele metode utilizate pentru acest scop, deoarece poate preveni apariţia cariilor dentare prin acţiunea fluorului din pastele de dinţi. Revelatorii pentru colorarea plăcii microbiene permit observarea cu uşurinţă a acesteia de către pacient şi identificarea precisă a zonelor de pe suprafețele dentare unde se acumulează frecvent sau persistă după îndepărtarea acesteia prin periaj personal, în cadrul igienizării orale. Folosirea revelatorului de placă favorizează conştientizarea de către pacient şi îl motivează pentru concentrarea atenţiei asupra zonelor colorate, favorizând astfel un control corect şi 
individualizat al plăcii dentare. La persoanele cu igienă orală precară, placa microbiană se acumulează şi favorizează apariţia cariilor dentare şi afecţiunilor gingivale. Astfel, menţinerea igienei orale prin controlul acumulării de placă microbiană este una dintre cele mai utilizate metode de prevenire a cariei dentare şi a bolii parodontale. Consolidarea motivaţiei pacientului în programele educaţionale şi preventive influenţează pozitiv reducerea nivelului de placă microbiană dentară, a riscului de apariţie a cariei şi sângerărilor gingivale. Folosirea revelatorilor de placă îmbunătățeşte astfel nivelul de igienă şi starea de sănătate orală (1).

Prin depistarea tiparului acumulării de placă bacteriană la nivelul nivelul suprafețelor dentare, putem identifica şi tiparul patologiei carioase şi parodontale viitoare şi stabili programe preventive cu caracter personalizat. Obiectivul principal al acestui studiu pilot este să evalueze distribuţia plăcii microbiene la nivelul suprafeţelor dentare cu ajutorul revelatorului de placă.

\section{MATERIALE ŞI METODĂ}

Pentru atingerea obiectivului propus, au fost examinaţi 15 pacienţi cu vârste cuprinse între 20 şi 38 de ani, în perioada iulie - august 2012, luânduse în considerare astfel 223 de dinţi, în total 892 de suprafeţe dentare laterale.

S-au colorat cu ajutorul revelatorului (Rondells Red (Directa)) - revelator sub formă de bulete de culoare roşie) feţele vestibulare, orale, meziale şi distale până la joncţiunea dento-gingivală, conform protocolului clinic de lucru al indicelui de placă O'Leary. Rezultatele au fost marcate într-o diagramă a arcadelor dentare prin haşurare. Au fost luate în calcul doar suprafețele dentare acoperite cu placă

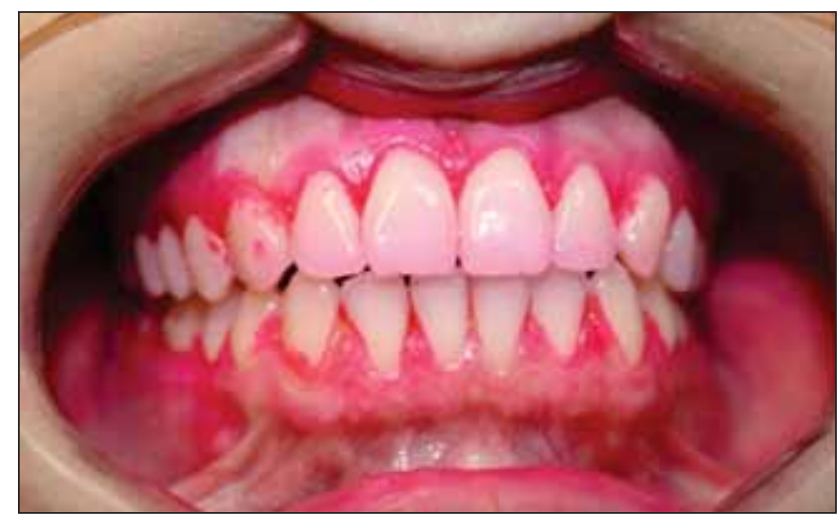

FIGURA 1 şi 2. Imagine frontală şi de profil după colorare colorată aflate în apropierea marginii gingivale, suprafeţe care au fost înregistrate şi notate cu "1". S-a calculat apoi indicele O'Leary, care este un indice procentual ((numărul suprafeţelor dentare cu placă x 100) / numărul de suprafeţe dentare examinate), pentru fiecare pacient în parte $(2,3)$.

\section{REZULTATE}

Scorurile indicelui O'Leary calculate după revelarea plăcii dentare (Fig. 1 şi 2) au fost contabilizate atât prin valoarea finală a indicelui pentru fiecare persoană în parte, care a dus la valoarea medie a lotului de studiat $(62 \%)$, cât şi pentru cele două arcade (Fig. 3) sau pentru fiecare tip de suprafaţă în parte (Fig. 4).

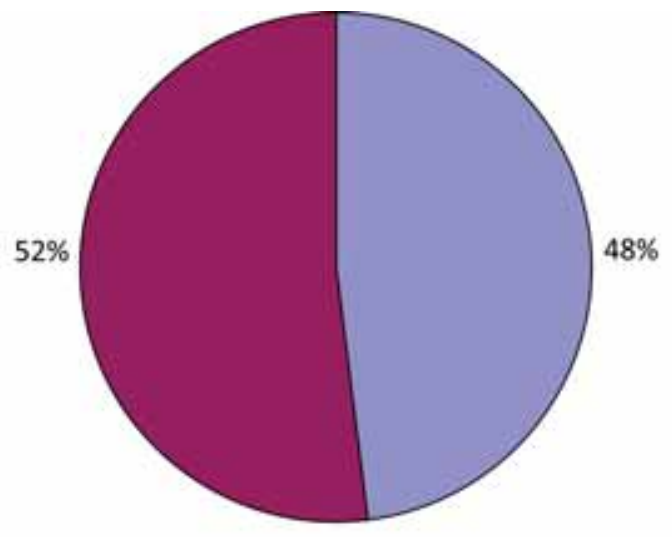

Suprafețe mandibulare

Suprafete maxilare

FIGURA 3. Distribuția procentuală a plăcii microbiene dentare la cele două arcade

De asemenea, au fost făcute analize privind distribuţia plăcii dentare la maxilar şi mandibulă pe tipuri de suprafeţe (Fig. 5), precum şi pe arcade şi tipuri de suprafeţe în zona frontală (Fig. 6) şi zona laterală (Fig. 7).

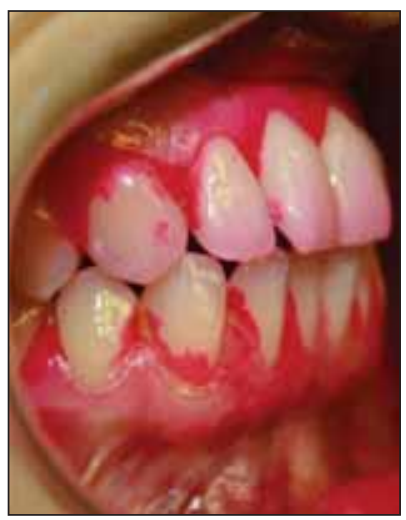




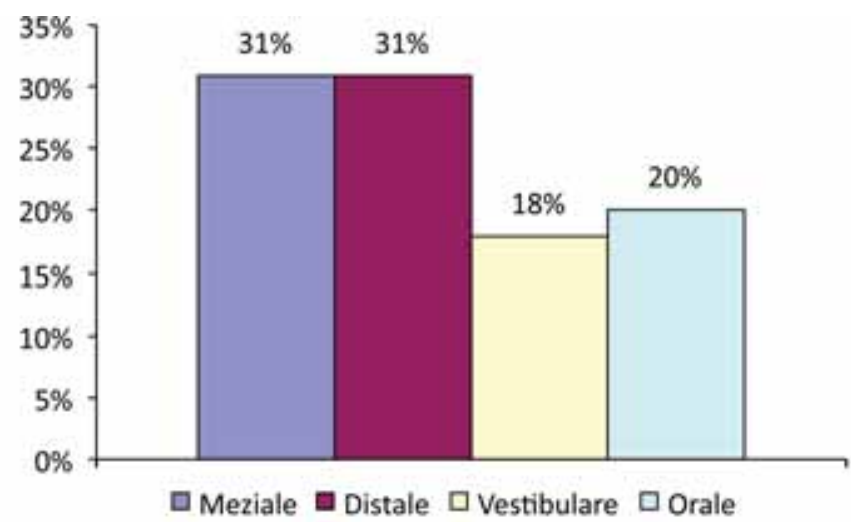

FIGURA 4. Distribuția procentuală a plăcii dentare pe tipuri de suprafețe

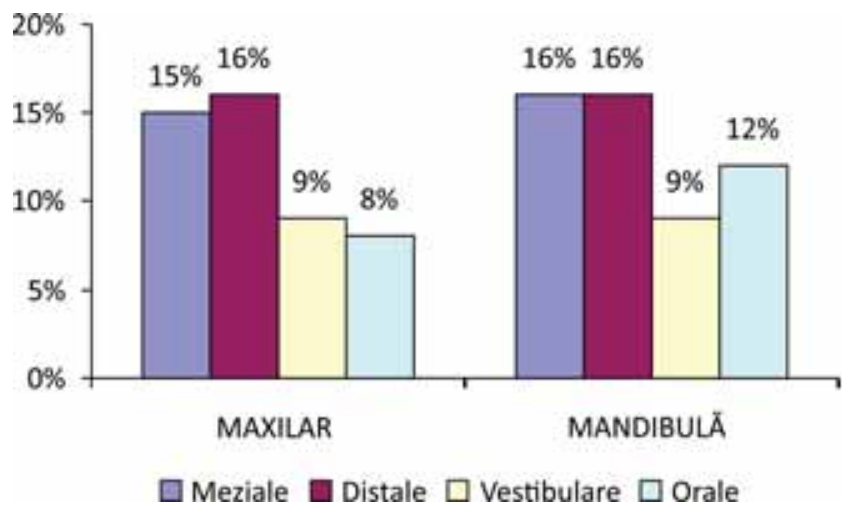

FIGURA 5. Distribuția procentuală a plăcii dentare pe arcade şi tipuri de suprafețe

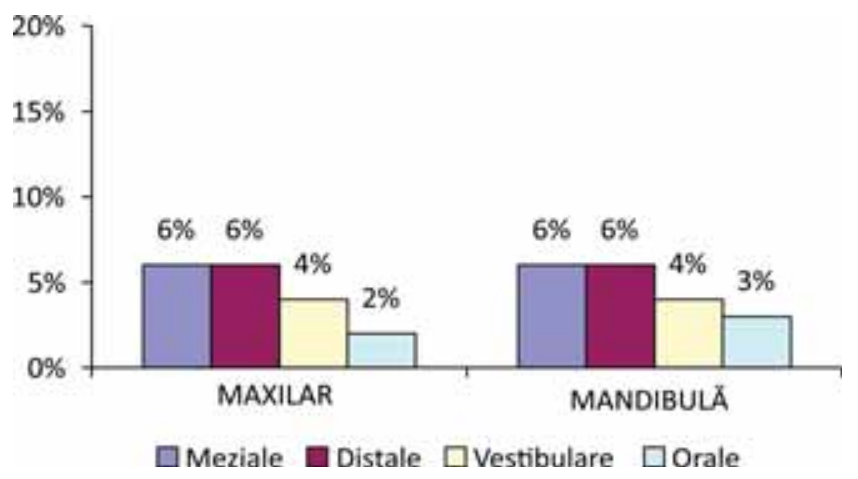

FIGURA 6. Distribuția procentuală a plăcii dentare pe arcade şi tipuri de suprafețe în zona frontală

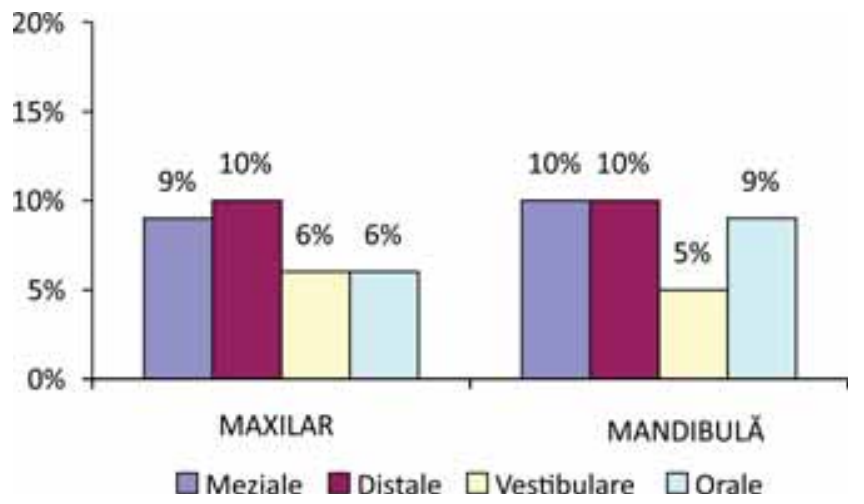

FIGURA 7. Distribuția procentuală a plăcii dentare pe arcade şi tipuri de suprafețe în zona laterală

\section{DISCUTुII}

Rezumând cele enunţate mai sus, putem spune că placa dentară este mai frecventă pe suprafeţele dentare maxilare, în speţă pe cele aproximale, unde există constant mai multă placă microbiană decât pe cele vestibulare sau orale. Din distribuţia plăcii dentare, expusă grafic, reiese şi faptul că suprafeţele orale ale dinţilor laterali mandibulari au frecvent mai multă placă faţă de restul suprafețelor orale, indicând probabil faptul că această zonă (orală laterală mandibulară) este mai greu de igienizat de către pacienţi. Aceeaşi concluzie se desprinde şi din studiul efectuat pe un eşantion reprezentativ de elevi de gimnaziu din Bucureşti, cu precizarea că o acumulare mai mare de placă se observă în special pe suprafeţele orale ale primului şi celui de-al doilea molar mandibular (2). Aceste suprafeţe prezintă, din cauza igienizării precare, atât mari acumulări de placă dentară, cât şi valori ridicate ale indicelui de sângerare, ceea ce sugerează un risc crescut de boală parodontală la acest nivel $(4,5)$.

Tiparul acumulărilor de placă bacteriană la nivelul arcadelor dentare depinde foarte mult şi de aliniamentul dinţilor, de diversele anomalii cu lipsă de spaţiu care predispun la o igienă orală dificil de realizat, precum şi de diversele tratamente protetice ce impun şi folosirea altor mijloace suplimentare pentru igienă orală. Astfel, programele preventive cu caracter individualizat trebuie să ţină cont atât de tiparul general de acumulare al plăcii, cât şi de factorii de risc ai individului: diversele anomalii dentare, dietă bogată în hidrocarbonate, tratamente protetice, carii, tartru, obturaţii debordante, aparate ortodontice sau alte elemente care duc la o retenţie suplimentară a plăcii microbiene pe anumite sectoare.

\section{CONCLUZII}

Tiparul de acumulare al plăcii dentare a cuprins în general feţele aproximale şi cele orale ale dinţilor mandibulari din zona laterală. Ţinând cont de acest lucru, programele preventive individualizate ar trebui să se bazeze pe acest tipar generalizat, dar şi pe factorii de risc care ţin de fiecare individ (înghesuiri dentare, consum de crescut de hidrocarbonate etc).

\section{Mulțumiri}

Dorim să mulţumim companiei Colgate-Palmolive România pentru sprijinul acordat. 


\section{BIBLIOGRAFIE}

1. Silva D.D., Gonçalo Cda S., Sousa Mda L., Wada R.S. Aggregation of plaque disclosing agent in a dentifrice. J Appl Oral Sci 2004; 12(2):154-158

2. O'Leary T.J., Drake R.B., Naylor J.E. The plaque control record. Journal of Periodontology 1972; 43(1):38

3. Ranga R., Cuculescu M., Funieru C., Tandără A., Sluşanschi O., Bănicioiu N. Aspecte practice în prevenţia oro-dentară. Editura Universitară Carol Davila, Bucureşti 2006;49-50
4. Funieru C., Klinger A., Băicuş C., Funieru E., Dumitriu H.T., Dumitriu A. Epidemiology of gingivitis in schoolchildren in Bucharest, Romania: a cross-sectional study. J Periodontal Res 2017;52(2):225-232

5. Ady M., Griffits G., Dummer P., Kingdom A., Shaw W.C. The distribution of plaques and gingivitis and the influence of toothbrusing hand in a group of South Wales 11-12 year-old children. J Clin Periodontol 1987;14:564-57.

Conflict of interest: none declared 